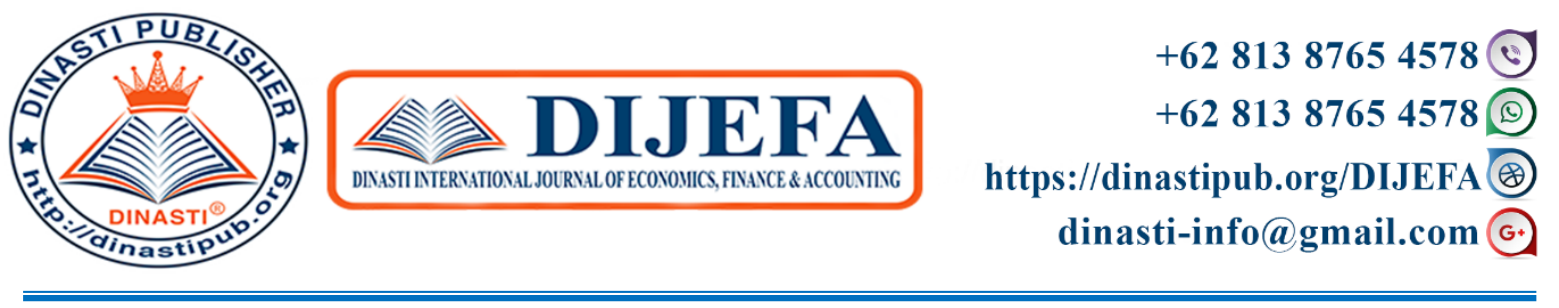

\title{
LITERATURE REVIEW FACTORS AFFECTING SERVICE PERFORMANCE: TRANSFORMATIONAL LEADERSHIP, TRUST ORGANIZATION AND ORGANIZATIONAL COMMITMENT
}

\author{
N. Ahmad Munawar ${ }^{1}$, Arviana Wulandari ${ }^{2}$, Asep Djalaludin ${ }^{3}$ \\ ${ }^{1)}$ Lecturer ASMK Bandung-Indonesia \\ ${ }^{2,3)}$ Lecturer at STIE Tribuana Bekasi-Indonesia
}

ARTICLE INFORMATION

Received: $24^{\text {th }}$ October 2020

Revised: $4^{\text {th }}$ November 2020

Issued: $22^{\text {nd }}$ November 2020

Corresponding author: First Author

E-mail:

munawar201969@gmail.com arvianawulandari@stietribuana.ac.id asepdjalaludin@gmail.com

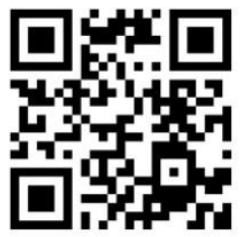

DOI: 10.38035/DIJEFA
Abstract: The development of information technology has an impact on the paradigm of global economic, organizational and geopolitical development. The speed in making the right decisions in an organization will determine the direction of business and business development of a company in response to intense competition, both nationally and globally. Effectiveness and efficiency in determining human resources are the main strategic factors in winning future business competition. Good human resource management is an absolute requirement in managing an organization that will affect the company's service performance. This paper is a review of the strategic relationship between Transformational Leadership, Trust Organization and Organizational Commitment on the performance of company services. This research was conducted by looking at the three factors that are considered to have an effect on service performance, namely the Transformational Leadership, Trust Organization and Organizational Commitment factors through various relevant research methods and can explain in detail the relationship between service performance factors and Transformational Leadership, Trust Organization and Organizational Commitment.

Keywords: Transformational Leadership, Trust Organization, Organization Commitment, Service performance

\section{INTRODUCTION}

Strategic human resource planning is the main pillar of how an organization manages human resources effectively and efficiently with the ultimate goal being the achievement of the vision and mission of the organization. Organizational goals will be achieved if the welfare of employees has a major place in managing the factors that affect human resources. Strategic 
planning factors such as budgeting, HR appraisal, selection, recruitment, hiring, employee dismissal, career development, organizational management, performance management, pesinun, industrial relationships, training and system development are absolute requirements for achieving company organizational goals.

The change in the paradigm of employee relations with the company which is so rapid has forced the company to change the paradigm of the relationship, which previously the company saw human resources as an object, that is, it considers that human resources are seen as a resource that one day will run out, so now the company views human resources is capital that has value if properly invested will provide benefits for the company or organization.

Good human resource management is when the management produces employee performance outputs in accordance with company expectations. The company expects that every employee has the ability to adapt to the rapid development of environment and technology so that it will result in high work productivity.

Many factors can affect service performance at a company, including a good relationship between employees and superiors, between employees and their work environment, and comfort at work, where this relationship will create employee satisfaction for the company. Due to employee satisfaction with the company, it will drive employee productivity higher and ultimately the company's service performance will also get better. Several factors that can improve the company's service performance include transformational leadership, trust in organization and organizational commitment.

Transformational leadership is a concept where the relationship between leaders and subordinates or followers elevates themselves to achieve higher levels of motivation and morality (Burns, 20: 1978). In the concept of transformational leadership, a leader is an agent of change in the organization. Change in the organization is marked by the existence of a clear and challenging organizational vision and mission in which a leader invites all of his followers to continue to strive to realize the stated vision and mission.

One of the achievements of organizational goals occurs because of the trust of employees in the company. This can be seen from the indicators in employee attitudes such as the presence of loyalty, the integrity, the propensity, the competence, the concern, the reliability. This attitude is a reciprocal of employee satisfaction with the company where this satisfaction will lead to an employee's trust in all decisions that the company makes against him.

One of the improvement in company service performance is the perception that there is a commitment of employees to stay in the company. Employees assume that what they have given the company so far has always received satisfying rewards from the company. Because of the employee's perception, a perception will arise in the employee that the company is always committed to realizing employee welfare and considers that employees are an important asset for the progress of the company.

Based on the background of the problem above, the problem formulation of this article is to review the theory of the effect of the independent variable on the dependent variable as shown below:

1) Does transformational leadership affect service performance

2) Does the trust organization affect service performance

3) Does organizational commitment affect service performance

\section{LITERATURE}

Service Performance 
Review Colquitt, (2011) explains that service performance is the value of a set of employee behaviors that contribute, either positively or negatively to the fulfillment of organizational goals. Performance is the result of work that has a strong relationship with the goals of organizational strategy, customer satisfaction, and contributes to the economy. Thus, performance is about doing work and the results achieved from the job (Armstrong, M. and Baron, A., 1998). Service quality is very important for customer satisfaction and trust.

In a study of service quality in banking service quality was found to have a positive effect on relationship quality, which includes customer satisfaction and trust. Service quality is an important factor affecting customer satisfaction ((Hsieh, YC, \& Hiang, ST, 2004). Paul, (2016) dividing the performance of banking services into nine dimensions, namely 1) Knowledge of product, namely employees' knowledge of products and services that banks have to offer to customers, 2) Response to need, namely the ability of employees to respond as quickly as possible to the needs of customers, 3) Solving question, namely the ability of employees to answer and provide solutions to customers, 4) Fast service, namely how employees are able to provide fast service in every aspect of banking services, 5) Quickly connected to the right person, employees are able to adapt to customer needs as quickly as possible so that the conversation to customers more focused t regarding services needed by customers, 6) Efforts to reduce queuing time, employees are able to overcome customer queues, 7) Pleased to be assisting you, employees feel happy in helping / serving customers, 8) Appearance, the overall appearance of both employees and outlets in the bank is visible good, 9) Follow up, employees are able to carry out every procedure that is owned by the bank.

According to Potluri (2016: 23) good bank service performance, influenced by prime service quality factors, in this study the service quality at banks uses the term BANKQUAL . "As the primary objective of the present paper is to develop a reliable measure of service quality, which is believed to be associated with customer satisfaction in the banking industry, an attempt is made to introduce a more robust alternative to SERVQUAL, namely BANKQUAL. The reliability of BANKQUAL is verified by Cronbach's alpha and found to be significant. The fundamental hypothesis for the study is that there is a strong association between service quality and customer satisfaction in banks and was found to be valid by using BANKQUAL (reliability, responsiveness, assurance, empathy, tangibles, competence, credibility, accessibility, communication, understanding, consulting, price, offering, influence, geographics). "

Service performance has been widely researched by previous researchers such as research conducted by Dedeoğlu, (2015), Huang (2016), Potluri (2016), and Paul (2016).

Based on the opinion of these experts, it can be synthesized that service performance is the result of the performance of employees serving customers. Service performance can be said to be successful if the services provided by employees to customers get a positive response from customers and can increase business growth for the organization / company. Service performance is influenced by several factors such as employee understanding of service, employee responsiveness, problem solving, speed of service, situation adaptation, initiative, service attitude, self-appearance and compliance.

\section{Transformational Leadership}

According to Colquitt (2011), leadership is the use of power and influence to direct flower activities towards goal achievement. That direction may influence followers' interpretation of events, the organization of their work activities, their commitment to important goals, their relationships with other followers, or their access to cooperation and support from other work units. In the concept of transformational leadership every action taken by a person to coordinate, direct, and influence others in choosing and achieving predetermined 
goals. Its main function is as a catalyst for change, not as a change controller (Suwatno, 2019). Transformational leadership is a leadership concept that involves change in organizations. Where in the concept of transformational leadership with its actions it can motivate employees to be willing to work for high-level goals that are considered to exceed their personal interests at that time (Avolio, et.al., 2004).

According to Yukl, G., (2010), transformational leadership is a condition in which the employees of a transformational leader feel trust, admiration, loyalty and respect for the leader and they are motivated to do more than what they initially expected. Meanwhile, according to (Graffeo, A.P, 2018), transformational leadership is the art and knowledge of creating the future by inspiring employees by informing the goals and desires to be achieved, building selfconfidence in every process that will be passed, gaining trust employees sincerely. This understanding makesaware usof the very important role of leaders in creating conducive and positive conditions for employees to move together in achieving goals in every organization.

To find out how much influence transformational leadership has in organizations, Banks (2016) divides it into 4 measurement dimensions, namely idealized influence (the tendency of individuals to encourage others to be similar to or in accordance with themselves), inspirational motivation (a situation in which individuals provide ideas or inspiration others follow it), intellectual stimulation characterizes (behavior in which individuals challenge their employees to argue or take other risks), individual consideration (behavior in which individuals try to meet and understand the needs of their employees). Banks (2016), Jaiswal, G., \& Sharma, M., (2019), (Boamah, SAet.al, 2018), say that transformational leadership can also be measured by using indicators of idealism, providing inspiration, providing intellectual support and wisdom.

Transformational leadership has been widely studied by previous researchers such as (Tucunan, RJA, et.al, 2014), Prafidya, H., (2017), Ahmed, et.al, (2015), Ariyabuddhiphongs (2017), Syaifudin, R ., et.al, (2018), and Yahaya, R., \& Ebrahim, F., (2016).

Based on the description above, it can be synthesized that transformational leadership is a leadership style where someone is able to encourage / motivate other people / employees to bring out all their abilities by continuing to provide inspiration and enthusiasm and being able to be used as role models for employees so that they can be trusted and followed consistently

\section{Trust In Organization}

Trust In Organization or trust in the organization is the most important factor for companies in controlling turnover intention and the sense of satisfaction of each individual employee with the company. Trust is not only important in organizational life; it is also an important element of social relations. Employee trust, which is felt by employees in the organization, can be a need and a factor that influences their organizational behavior positively or negatively (Tüzün, 2007).

Trust is a positive expectation that other people will not act opportunistically. Opportunistic refers to the risk and vulnerability of employees in trust-based relationships (Robbins, SP \& Judge, TA, 2015). Trust is associated with the word dependency and risk, namely dependence on people or goods that are trusted and the risk of the possibility that what is expected does not happen (Nooteboom, B., \& Six, F. (Eds.)., 2003). According to Robbins, P Stephen, Mary Coulter (2014), Organizational Justice has a very important role in the sense of fairness experienced by employees. There are three dimensions of a sense of fairness that is felt by employees, namely Distributive Justice which focuses on ways of providing compensation to employees. The compensation referred to here is related to the wages / salaries received by employees or other bonuses, the amount of which of course adjusts the 
performance of the employee. The second is Procedural Justice, a decision on an issue that can have an impact on a sense of injustice in the minds of employees, especially if during decision making, employees do not have room for disagreement. And the third is Interactional Justice which refers to the interactions of employees with other employees and with their superiors where respect and mutual respect are emphasized in shaping justice. These three dimensions of Organizational Justice have an impact on whether employees are satisfied or not at work. Tranter, B., \& Skrbiš, Z., (2009), divides two factors that can influence trust, namely 1) Rational factors Rational factors are strategic and calculative in other words, people can be trusted because they have special skills or have a professional position. The person giving the trust (the trustor) can estimate whether the person who has the trust (trustee) can carry out the trustor's demands. The view that the emergence of trust generally comes from rational factors and the assumption that in order to give trust (trust) to others, information or knowledge about it must first be obtained. 2) The relational factor in this case Mishler, W. \& Rose., (2001) argues that trust is conditioned through culture and experience, beliefs about people who can work in political institutions. Trust comes from superior perceptions and attributions about trustworthiness from ability, virtue, and integrity (Meyer, 2013).

According to Zeffane (2017) trust in organization can be measured by six benchmarks, namely The Benevolence Dimension of Trust, The Integrity Dimension of Trust, The Credibility Dimension of Trust, The Competence Dimension of Trust, The Concern Dimension of Trust and The Reliability Dimension of Trust.

Trust in organizations have been researched and analyzed by previous researchers including those conducted by Zeffane, (2017), Yang, J. (2010), Leck, J., \& Orser, B (2013), Dirks, KT, \& Ferrin, DL, (2001).

From the descriptions of the experts and the results of the analysis of previous researchers, it can be synthesized that trust is a positive expectation where other people will not act opportunistically. Opportunistic attitudes refer to the risk and vulnerability of employees in trust-based relationships. Trust is widely associated with the word dependence and risk, namely dependence on people or goods that are trusted and the risk of the possibility that what is expected will not happen. There are several dimensions as a measure of a trust in organization including; the benevolence dimension of trust, the integrity dimension of trust, the propensity dimension of trust, the competence dimension of trust.

\section{Commitment Organizational}

commitment is a condition in which employees take sides with a particular organization and its goals and have the desire to remain as members in the organization (Robbins \& Judge, 2015). According to Newstrom, JW, (2002), Organizational commitment is the level where individuals side with the organization and want to continue their active participation in the organization. Organizational commitment is the degree to which employees are involved in their organization and desire to remain as members, which contains loyalty and willingness of employees to work optimally for the organization where the employee works (Greenberg, JA, 2003).

According to Allan and Mayer (1990), that organizational commitment refers to the emotional attachment of employees to the organization. Where the normative component refers to the employee's feeling of obligation to remain with the organization. Organizational commitment is emotional attachment, identification and involvement of individuals with the organization and the desire to remain a member of the organization. According to Luthan (2006), there are several definitions of organizational commitment as employee attitudes towards the company such as organizational commitment can be defined as a strong desire to remain part of a particular member of the organization and can also be defined as organizational 
commitment as the desire to strive according to the wishes of the organization; c) certain beliefs, acceptance of values, and organizational goals. Therefore, organizational commitment is a reflection of employee loyalty to the company. Where all members of the organization express their concern for the organization and its success and continuous progress. Whereas Dessler, (2002) defines organizational commitment as employee identification of approval to achieve the unit mission or organizational mission. Organizational commitment arises as a result of satisfaction with what employees feel about the company returns. This commitment is needed so that workers are always loyal to where they work. Loyal workers are ensured to reduce the turnover rate that occurs in each organization. (Yousef, DA, 2017),

According to Posey, CR (2015) there are three dimensions that can measure employee organizational commitment to the company, including 1) affective organizational commitment, namely commitment that is formed due to the desire of employees to continue wanting to join the organization / company because value, the goals the company wants to achieve are in accordance with employees, 2) continuance organizational commitment, that is, employees take into account to stay with the company because of the profit and loss factors when leaving the company and other companies are considered unable to be like the state of the company where they are currently working, 3) Normative organizational commitment, that is, employees feel they have to stay at the company because they believe or believe they (employees) have invested a lot of time (long working period) for the company, making it difficult to leave the company.

Analysis of organizational commitment has been done by previous researchers such as research conducted by Wu, (2018), Posey, CR (2015), Mickahail,BK (2019), Adjibolosoo, (2018), Kim,T.Henderson., Enom., (2015), Fu., (2014), Hafiz, (2017), Asiedu., Sarfo., And Adjei. (2014), Kim, SS, Shin, D., Vough, HC, Hewlin , PF, \& Vandenberghe, C., (2018), Suliman, A., \& Kathairi, M. Al. (2013), Dinc, MS, Kuzey, C., \& Stefan. (2018).

From the description of the experts above and the results of the analysis of previous researchers, it can be synthesized that organizational commitment is emotional attachment, identification and involvement of individual employees with the organization and the desire to remain a member of the organization. Organizational commitment can be measured by the dimensions of organizational commitment such as affective organizational commitment, continuance organizational commitment and Normative organizational commitment.

\section{RESEARCH METHODS}

The method of writing scientific articles is by qualitative methods and literature study or Library Research. Review literature books according to the theory discussed, especially in the scope of Human Resource Management (HRM). Besides, it analyzes reputable scientific articles as well as scientific articles from journals that are not yet reputable. Allscientific articles are cited sourced from Mendeley and Google Scholar.

In qualitative research, literature review should be used consistently with methodological assumptions. This means that it must be used inductively so that it does not lead to the questions posed by the researcher. One of the main reasons for conducting qualitative research is that it is exploratory in nature (Ali \& Limakrisna, 2013).

Furthermore, it is discussed in depth in the section entitled "Related Literature" or literature review ("Review of Literature"), as a basis for the formulation of hypotheses and will then become the basis for making comparisons with the results or findings revealed in the research. (Ali \& Limakrisna, 2013).

RESULTS AND DISCUSSION

Relationship or influence between exogenous variables and endogenous variables. 
This article analyzes and discusses the variables of Human Resource Management (HRM), namely: Transformational Leadership, Trust Organization, Organizational Commitment, Service performance.

\section{Transformational Leadership has a relationship and has an effect on Service Performance}

Transformational leadership affects Service Performance, this statement is based on articles from relevant research and reviewed, including by: Tucunan, RJet.al, (2014), Suwito, R. \&. Yolanda (2018), Serhan, CA (2018), Nijhawan, SP (2014), Akhtar, NA (2014), Brych, VY (2018), Ismail, AA (2016) and Chauhan, R., Ali, H., \& Munawar, NA (2019)

In one of the results of the research analysis explains that transformational leadership is very important in the development and achievement of organizational goals. The achievement of organizational or company goals is due to an increase in the performance of each individual employee so that it has an effect on the service performance of the company or organization as a whole. An increase in employee productivity or performance will occur if the company considers that each individual employee is a company asset which, if developed, will generate benefits for the company as a whole.

Transformational leadership is a concept in which leaders from low level to top management become agents of change and become a guide and motivator for their subordinates. So that each attitude is a role model for the progress of his subordinates. Inthe era of globalization which is full of challenges, in order for an organization to survive, it is very necessary for a leader who can become a role model for his subordinates, who is able to be an example or an example for those they lead. This example or example is important because it will become a magnet for the subordinates they lead to follow and carry out what the leader wants. Leaders can influence and direct employees to achieve company goals, so employees will work well so that an increase in the company's overall service performance is achieved.

Based on the description above, Transformational Leadership contains the ability to improve the performance of each individual employee. Each leader will carry out guidance to increase the work ability of subordinates so that each individual employee feels support and direct attention from their superiors which has an effect on increasing employee confidence in carrying out tasks assigned by the boss. Increasing the competence of each individual employee of course will have the effect of increasing the overall performance of the company so that the goals of the organization or company will be achieved by itself.

\section{Trust in Organizations have a relationship and influence on Employee Performance}

Trust in organizations have an effect on Service Performance, this statement is based on articles from relevant research and reviews, including by: Indrawardhani, RD, \& Fitri, W. (2020), Chaouali, W.et.al (2016), Luo, X.et.al (2010), Shirvani, SM (2020), Purwaningrum, T., \& Chamidah, S. (2020) and Dehghanpouri(2020).

This article explains that if the employee's trust in organization contributes to the improvement of the company's service performance. Trust is a positive expectation that other people will not act opportunistically. Opportunistic refers to the risk and vulnerability of employees in trust-based relationships. Trust has been considered as a catalyst in a variety of business and social relationships. Trust will lead to satisfaction because the desired results are materialized as expected. In employee and company relationships, trust in the organization will increase the productivity of each individual employee.

Organizational trust will result in attitudes from employees such as policies in disclosing various issues in the company, employee integrity towards the company, the tendency to comply with company decisions and increasing work competence of each 
individual employee. Because these factors are inherent in each individual employee, it will have a positive effect in increasing employee understanding of the company, increasing employee responsiveness in serving customers or issues in the company, increasing employee competence in solving every problem, encouraging service speed for the sake of achieving customer satisfaction, being able to adapt to changing situations that are and will take place in the company, the emergence of initiatives to serve from each individual employee, always pay attention to personal appearance to foster a sense of professionalism and customer confidence and increase the level of compliance with all rules and policies issued by the company

So it is clear based on the description above, the trust in organization will have a positive impact on increasing employee productivity and performance so that the ultimate goal of the company is to improve the overall service performance of the company.

\section{Organizational Commitment has a relationship and affects Service Performance}

Organizational commitment affects Service Performance, this statement is based on articles from relevant research and is reviewed, including: Bastari.et.al (2020), Kosasih, YS (2014), Wahyudi ,N.K. \& Sudibya (2016), Fu, W. \&. Deshpande (2014), Hafiz (2017), Asiedu (2014), Kim (2018), Suliman, A. \&. Khathairi.M (2013), and Dinc, M. S (2018).

This article indicates that organizational commitment directly affects employee performance and thus has broad importance. Organizational commitment is an idea that has attracted a wide range of human resource management practitioners and scholars because it affects organizational and employee performance. Employee commitment is very important to organizational performance. Commitments are taken as future agreements for specific tasks under special circumstances and times.

Employee beliefs and behavior for an organization is referred to as organizational commitment. Organizational commitment is an important work-related outcome at the individual level, which may impact work-related outcomes such as performance. Employees who have high organizational commitment will have a higher level of performance, because highly committed employees will work hard and make the necessary sacrifices for the organization. Individuals will take jobs, identify with job-related roles, they will become committed to doing the job and behave in accordance with the expectations of the job. Organizational commitment is a condition in which an individual is loyal to his organization and wants to defend himself in the organization. The higher the employee's organizational commitment, the higher the employee's performance.

\section{Conceptual Framework \& Hypotheses}

Based on the study of theories and relationships between variables, the model or Conceptual Framework of this article in order to construct a hypothesis is as follows:

1) The Influence of Transformational Leadership on Service Performance, based on the results of research analysis by Tucunan, RJet.al, (2014), Suwito, R. \&. Yolanda (2018), Serhan, CA (2018), Nijhawan, SP (2014), Akhtar, NA (2014), Brych, VY (2018), and Ismail, AA (2016).

2) The effect of trust in organization on service performance, based on the research results of Indrawardhani, RD, \& Fitri, W. (2020), Chaouali, W.et.al (2016), Luo, X.et.al (2010), Shirvani, SM ( 2020), Purwaningrum, T., \& Chamidah, S. (2020) and Dehghanpouri(2020).

3) The Influence of Organizational Commitment on Service Performance, based on research results Bastari.et.al (2020), Kosasih, YS (2014), Wahyudi, NK \& Sudibya (2016), Fu, W. \&. Deshpande (2014), Hafiz (2017), Asiedu (2014), Kim (2018), Suliman, A. \&. Khathairi.M (2013), and Dinc, M. S (2018). 
From the formulation of the problem of writing this article and reviewing literature studies from both relevant books and articles, the processed framework of this article isas below.

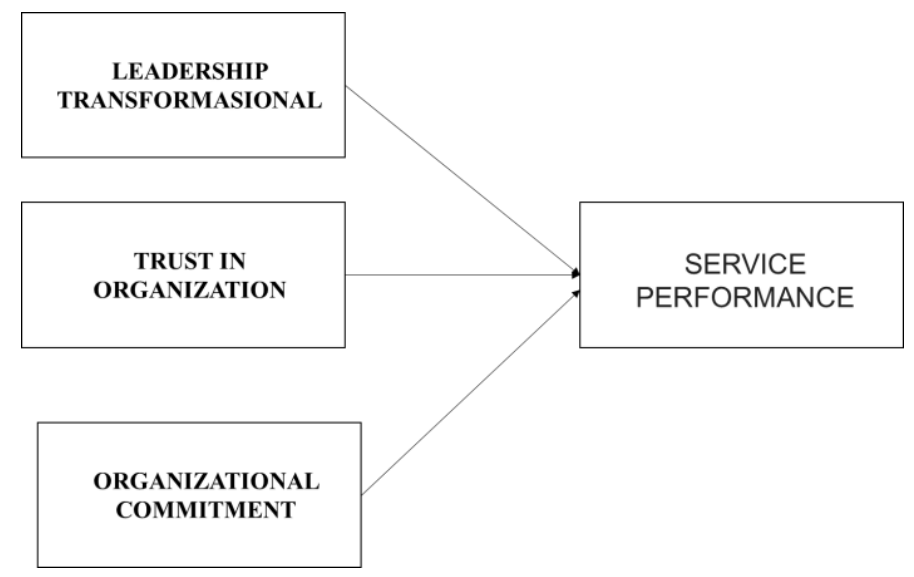

\section{Picture 1: Conceptual Framework}

Based on theoretical studies, review of research results from relevant journals and images from the conceptual framework, hypotheses can be formulated for further research, namely:

1) Transformational Leadership affects Service Performance

2) Trust In Organization affects Service Performance

3) Organizational Commitment affects Service Performance

\section{CONCLUSIONS AND SUGGESTIONS}

\section{Conclusions}

Based on the formulation of the article, the results and discussion that were reviewed and discussed in this article, it can be concluded that to build a hypothesis for further research are:

1) Transformational Leadership has an effect on Service Performance. The application of the Transformational Leadership concept to the company must be consistent so that it can significantly influence the overall service performance of the company.

2) Trust In Organization affects Service Performance. Trust can grow if employees' perceptions of the company are good. Employees believe in the organization or company where they take shelter and make it a place to fulfill the expectations that employees want to achieve. If this can be implemented, the Trust In Organization will have a positive and significant effect on the company's service performance.

3) Commitment Organizational has an effect on Service Performance. Organizational commitment is a driving force for improving the performance of each individual employee. Employees will be committed to providing the best contribution to the company if the support from the organization or company can be felt by the employees themselves. Because the support from the organization has been felt by the employees, it will significantly affect the employee's performance which in the end the overall company Service Performance will be achieved.

\section{Suggestion}

In relation to the results of the analysis above, it is hoped that all companies and organizations can maximize service performance by increasing various supporting factors that affect the company's service performance. In addition, it is also hoped that the company will 
continue to improve the quality and quantity given in relation to the company's output in order to advance the company's development. This paper can also be developed again with more detailed methods both qualitative and quantitative in nature.

\section{BIBLIOGRAPHY}

Adjibolosoo, S. (2018). A Human Factor Approach to Human Resource Management and Organizational Development. In The Human Factor Approach to Managerial and Organizational Efficiency and Effectiveness. . Palgrave Macmillan: , Cham.

Ahmed, I., Nawaz, M. M., Ali, G., \& Islam, T. . (2015). Perceived organizational support and its outcomes. . Management Research Review.

Akhtar, N. A. (2014). Factors affecting employees motivation in banking sector of Pakistan. . Journal of Asian Business Strategy, 4(10), 125.

Ali, H., \& Limakrisna, N. (2013). Metodologi Penelitian (Petunjuk Praktis untuk Pemecahan Masalah Bisnis, Penyusunan Skripsi, Tesis, dan Disertasi). Yogyakarta: Deeppublish.

Allen, N. J., \& Meyer, J. P. (1990). The measurement and antecedents of affective, continuance and normative commitment to the organization. Journal of occupational psychology, , 63(1), 1-18.

Amstrong., \&. M. (2011). Performance management. . Yogyakarta: Tugu Publisher.

Ariyabuddhiphongs, V. \&. (2017). Transformational leadership and turnover intention: The mediating effects of trust and job performance on café employees in Thailand. . Journal of Human Resources in Hospitality \& Tourism, , 16(2), 215-233.

Armstrong, M. and Baron, A. . (1998). Performance Management - The New Realities. London: Institute of Personnel and Development.

Asiedu., Sarfo., and Adjei. . (2014). Organisational commitment and citizenship behaviour: tools to improve employee performance; an internal marketing approach. European Scientific Journal, , 10(4).

Avolio, B. J., Zhu, W., Koh, W., \& Bhatia, P. (2004). Transformational leadership and organizational commitment: Mediating role of psychological empowerment and moderating role of structural distance. Journal of Organizational Behavior: The International The International Journal of Industrial, Occupational and Organizational Psychology and Behavior, , 25(8), 951-968.

Banks, G. C. (2016). A meta-analytic review of authentic and transformational leadership: A test for redundancy. The leadership quarterly,.

Bastari, A., \& Hapzi Ali, H. (2020). Service Performance Model Through Work Motivation: Analysis of Transformational Leadership, Managerial Coaching, and Organizational Commitments (At the Regional Development Bank of South Kalimantan). Systematic Reviews.

Boamah, S. A., Laschinger, H. K. S., Wong, C., \& Clarke, S. (2018). Effect of transformational leadership on job satisfaction and patient safety outcomes. , . Nursing outlook, 66(2), 180-189.

Brych, V. Y. . (2018). Prospects for use of coaching in Ukrainian banks. . Banks and Bank Systems, 13(2), 116.

Burn, J. M. (1978.). Leadership. . New York: Harper \& Row.

Chaouali, W., Yahia, I. B., \& Souiden, N. ( 2016). The interplay of counter-conformity motivation, social influence, and trust in customers' intention to adopt Internet banking services: The case of an emerging country. Journal of Retailing and Consumer Services, , 28, 209-218. 
Chauhan, R., Ali, H., \& Munawar, N. A. (2019). BUILDING PERFORMANCE SERVICE THROUGH TRANSFORMATIONAL LEADERSHIP ANALYSIS, WORK STRESS AND WORK MOTIVATION (EMPIRICAL CASE STUDY IN STATIONERY DISTRIBUTOR COMPANIES). Dinasti International Journal of Educatio of Education Management And Social Science., https://doi.org/10.31933/dijemss.v1i1.42.

Colquitt, J. A. (2011). Organizational Behavior: Improving Performance and Commitment in the Workplace. (2nd Edition). . New York: McGraw Hill.

Dedeoğlu, B. B. (2015). Differences in service quality perceptions of stakeholders in the hotel industry. . International Journal of Contemporary Hospitality Management.

Dehghanpouri, H. S. (2020). The impact of trust, privacy and quality of service on the success of E-CRM: the mediating role of customer satisfaction. Journal of Business \& Industrial Marketing.

Dessler, G. (2002). Human Resource Management. . New Jersey.: Prentice Hall.

Dinc, M. S., Kuzey, C., \& Steta, N. . (2018). Nurses ' job satisfaction as a mediator of the relationship between organizational commitment components and job performance. Journal of Workplace Behavioral Health,, $0(0)$, 1-21. doi:https://doi.org/10.1080/15555240.

Dirks, K. T., \& Ferrin, D. L. (2001). The role of trust in organizational settings. Organization science, $12(4), 450-467$.

$\mathrm{Fu}$, W. \&. Deshpande. (2014). The impact of caring climate, job satisfaction, and organizational commitment on job performance of employees in a China's insurance company. Journal of Business Ethics, 124 (2), 339-349. Diambil kembali dari https://link.springer.com/a.

Graffeo, A. P. (2018). Leading Science and Technology-Based Organizations: Mastering the Fundamentals of Personal, Managerial, and Executive Leadership. CRC Press.

Greenberg, J. A. . (2003). Behavior in Organization International Edition,. New Jersey: : P: rentice Hall.

Hafiz, A. Z. (2017). Relationship between organizational commitment and employee's performance evidence from banking sector of Lahore. ,., . Arabian Journal of Business and Management Review, 7(2), 1-7.

Hsieh, Y. C., \& Hiang, S. T. (2004). A study of the impacts of service quality on relationship quality in search-experience-credence services. Total Quality Management \& Business Excellence, 15(1), 43-58.

Huang, L. C. (2016). High performance work systems, employee well-being, and job involvement: An empirical study. Personnel Review, 45(2), 296-314.

Indrawardhani, R. D., \& Fitri, W. . (2020). PENGARUH PERSON ORGANIZATION FIT (PO-FIT) DAN ORGANIZATION TRUST MELALUI EMPLOYEE ENGAGEMENT TERHADAP KINERJA KARYAWAN PADA PDAM TOYA WENING SURAKARTA . (Doctoral dissertation, IAIN SURAKARTA).

Ismail, A. A. . (2016). Managerial Coaching in Enhancing Employees' Motivation. Acta Universitatis Danubius: Oeconomica, 12(3), 98-112. Diambil kembali dari Retrieved from

http://search.ebscohost.com/login.aspx?direct=true \&db=bth\&AN=116779570\&site=e host.

Jaiswal, G., \& Sharma, M. (2019). The Relationship between Trust, Learning Capability and Affective Organizational Commitment. The Relationship between Trust, Learning Capability and Affective Organizational Commitment. 
Kim, S. S. (2018). How do callings relate to job performance? The role of organizational commitment and ideological contract fulfillment. Human Relations,, 71(10), 13191347. doi:doi:10.1177/0018726717.

Kim, S. S., Shin, D., Vough, H. C., Hewlin, P. F., \& Vandenberghe, C. (2018). How do callings relate to job performance? The role of organizational commitment and ideological contract fulfillment. , . Human Relations, $71(10)$, 1319-1347. doi:doi:10.1177/0018726717.

Kim, T. Henarson.,Enom. (2015). At the front line: examining the effects of perceived job significance, employee commitment, and job involvement on public service motivation. „.. International Review of Administrative Sciences, 81(4), 713-733.

Kosasih, Y. S. (2014). Pengaruh budaya dan Komitmen Organisasionalonalonal terhadap kinerja karyawan. Agora, .

Leck, J., \& Orser, B. (2013). Fostering trust in mentoring relationships: An exploratory study. Equality, Diversity and Inclusion. doi:https://doi.org/10.1108/EDI-01-2010-0007.

Luo, X., Li, H., Zhang, J., \& Shim, J. P. (2010). Examining multi-dimensional trust and multifaceted risk in initial acceptance of emerging technologies: An empirical study of mobile banking services. Decision support systems, , 49(2), 222-234.

Luthans, F. (2006). Perilaku Organisasi. . Yogyakarta : Andi.

Meyer, A. a. (2013). The Measurement and Antecedents of Affective, Contintinuance and Normative Commitment to Organitazion . Jakarta: PT Elex Media Komputindo.

Mickahail, B. K. (2019). Effective and Creative Leadership in Diverse Workforces. Springer.

Mishler, W. \& Rose. (2001). What are the origins of political trust? Testing institutional and cultural theories in post-community societies, 34, no.1.

Newstrom, J. W. (2002). Organizational Behaviour (11th ed.). New York: McGraw-Hill/Irwin.

Nijhawan, S. P. (2014). New key to employee retention-intrinsic motivation: A study of private banking sector of India. 2(1), 90-95.: JIR, .

Nooteboom, B., \& Six, F. (Eds.). ( 2003). The trust process in organizations: Empirical studies of the determinants and the process of trust development. . Edward Elgar Publishing.

Paul, J. M. (2016). Impact of service quality on customer satisfaction in private and public sector banks. . International Journal of Bank Marketing,, 34(5), 606-622. doi:https://doi.org/10.1108/IJBM-03-2015-0030.

Posey, C. R. . (2015). The impact of organizational commitment on insiders' motivation to protect organizational information assets. Journal of Management Information Systems, 32(4)179-214. doi:https://www.tandfonline.com/doi/abs/10.1080/07421222.2015.1138374.

Potluri, R. M. (2016). A structural compendium on service quality and customer satisfaction A survey of banks in India. . Journal of Transnational Management, 21(1), 12-28.

Prafidya, H. (2017). PENGARUH KOMITMEN ORGANISASI DAN PERCEIVED ORGANIZATIONAL SUPPORT TERHADAP TURNOVER INTENTIONS KARYAWAN PADA PT PLN (PERSERO) DISTRIBUSI JAWA TIMUR AREA SURABAYA UTARA. Jurnal Ilmu Manajemen (JIM),, 5(2).

Purwaningrum, T., \& Chamidah, S. ( 2020). The Effect of Interpersonal Trust and Need of Achievement on the Lecturers' Performance (Study at Universitas Muhammadiyah Ponorogo). Ekuilibrium: Jurnal Ilmiah Bidang Ilmu Ekonomi, , 15(2), 188-195.

Robbins, P Stephen,Mary Coulter. ( 2014). Manangement, Twelfth Edition. . United States: Pearson Education Limited.

Robbins, S.P. \& Judge, T.A. (2015). Organizational Behavior (16th ed). Upper Saddle River. New Jersey: Pearson Education, Inc. 
Serhan, C. A. . (2018). Understanding Public Sector Employees' Motivation: What makes them Inspired. . International Journal of Human Resource Studies, , 8(1), 249-273.

Shirvani, S. M. . (2020). Influential factors of foreign exchange services marketing with trust mediator role in Iranian international banking industry. . International Journal of Business Innovation and Research, , 22(2), 229-242.

Suliman, A., \& Kathairi, M. Al. (2013). Organizational justice, commitment and performance in developing countries:The case of the UAE. Employee Relations, , 35(1), 98-115. doi:https://doi.org/10.1108/01425451311279438.

Suwatno. (2019). Pemimpin dan Kepemimpinan Dalam Organisasi Publik dan Bisnis. . Jakarta:: Bumi Aksara.

Suwito, R. \&. Yolanda. (2018). Analisis Motivasi Kerja Karyawan Pada Pt. Bank Sumut Kcp Marelan Medan. . Jurnal Bis-A: Jurnal Bisnis Administrasi, , 2(2).

Syaifudin, R., Wulan, H. S., \& Diana, P. . (2018). The Effect Of Transactional Leadership Style, Role Conflict And Career Development On Organizational Citizenship Behavior Educated Affective Commitment (Study On Production Employees PT. Inti Sukses Garmind.

Tranter, B., \& Skrbiš, Z. (2009). Trust and confidence: A study of young Queenslanders. Australian Journal of Political Science,: 44(4), 659-678.

TUCUNAN, R. J. A., SUPARTHA, W. G., \& RIANA, I. G. (2014). The Effect of Transformational Leadership on Employee Motivation and Performance. E-Journal of Economics and Business, Udayana University, , 3, 533-550.

Tüzün, İ. K. (2007 ). Güven, örgütsel güven ve örgütsel güven modelleri. . Karamanoğlu Mehmetbey Universitesi Sosyal ve Ekonomik Araştırmalar Dergisi, , 2007(2), 93-118.

Wahyudi, N. K. \& Sudibya. (2016). Pengaruh Kepuasan Kerja dan Komitmen Organisasionalonalonal Pada Kinerja Karyawan Di Natya Hotel, Kuta Bali. ). . EJurnal Manajemen, $\quad 5(2$. doi:https://ojs.unud.ac.id/index.php/Manajemen/article/view/16090.

Wu, C. M. (2018). Collective psychological capital: Linking shared leadership, organizational commitment, and creativity. . International Journal of Hospitality Management, 74, 75-84.

Yahaya, R., \& Ebrahim, F. (2016). Leadership styles and organizational commitment: literature review. In Journal of Management Development. , https://doi.org/10.1108/JMD-012015-0004.

Yang, J., \& Mossholder, K. W. ( 2010). Examining the effects of trust in leaders: A bases-andfoci approach. . The Leadership Quarterly, , 21(1), 50-63.

Yousef, D. A. (2017). Organizational commitment, job satisfaction and attitudes toward organizational change: A study in the local government. . International Journal of Public Administration,,, 40(1), 77-88. doi: https://doi.org/10.1080/01900692.2015.107221.

Yukl, G. (2010). Leader Ship In Organizational, Upper Saddle River. New Jersey: : Pretince Hall.

Zeffane, R., \& Melhem, S. J. B. (2017). Trust, job satisfaction, perceived organizational performance and turnover intention. Employee Relations. 